\title{
The Influence of Transformational Leadership Behaviours on Oman Public Employees' Work Performance
}

\author{
Salim Musabah Bakhit Al Zefeiti ${ }^{1,2}$ \\ ${ }^{1}$ Universiti Teknologi Malaysia, Malaysia \\ ${ }^{2}$ Royal Court Affaris, Oman \\ Correspondence: Salim Musabah Bakhit Al Zefeiti, E-mail: albatinah@hotmail.com
}

Received: January 1, 2017

Accepted: January 13, 2017

Online Published: February 15, 2017

doi:10.5539/ass.v13n3p102

URL: http://dx.doi.org/10.5539/ass.v13n3p102

\begin{abstract}
The purpose of this paper is to investigate the influence of transformational leadership behaviors work performance in the context of Omani governmental organizations. The research emphasizes that transformational leadership is a crucial element to enhance employees' performance. Transformational leadership Inventory was used to measure transformational leadership behaviors. Contextual and task performance were used to measure work performance. Quantitative survey method was applied and a sample of 335 middle-level managers of Omani public civil service organizations was selected to answer the instrument. Analysis of Moment Structures (AMOS) was utilized to analyse the collected data and test the research questions, and hypotheses. The techniques of data analysis comprised descriptive statistics, a Confirmatory Factor Analysis (CFA), and a Structural Equation Modeling (SEM) analysis. The empirical results indicate that transformational leadership behaviours (core transformational leadership, providing individualized supports, intellectual stimulation, and setting high performance expectation) have a significant impact on contextual performance. Whereas, core transformational leadership and providing individualized supports have a significant impact on task performance.
\end{abstract}

Keywords: Contextual performance, Oman, Public organization, Task performance, Transformational Leadership behaviors, Work performance

\section{Introduction}

In recent years, organizations have been living in an era where change becomes inevitable, and they are operating dynamically, which, in turn, require a very quick response to the fast movement in business domain. The challenge of performance improvement in organizations has intensified along with the struggle to supervise the quality of the workplace and globalization, international trade, the rising expectation of citizens, and accelerated competition among organizations all have led to organizations' focusing, particularly, on the quality within the contexts of the past few decades (Akdere, 2006). Organizations have different sources distinguish them from their competitors; some of these sources are the leader's ability to fuse organization production skills and new technologies into practice that empowers specific entities to familiarize the rapidly changed chances (Hamel \& Prahalad, 1990).

Transformational leaders influence followers and drive organizational changes by promoting process values such as honesty, loyalty, and fairness, while emphasizing the end values of justice, equality, and human rights (Mendonca, 2001). Transformational leaders raise their subordinates' emotions instead of depending on rational process to motivate them (Moss \& Ritossa, 2007). Leaders have positive effects on their subordinates by creating a sense of attachment to the job, being fair, and recognizing good performance (Macey \& Schneider, 2008).

Indeed, all over the world public organizations face numerous challenges and obstacles to be more responsive to the needs of citizens (Nusair et al., 2012). Oman is no exception; after raising expectation of Omani citizens, the Omani government has encouraged Omani public organizations to develop and enhance their performance (Ministry of Civil Service, 2012).

Earlier researcher (Ali et al., 2014; Dvir et al., 2002; Givens, 2011; Joo \& Lim, 2013; Jose \& Mampilly, 2014; Lee et al., 2007; Manaf \& Latif, 2014; Miao et al., 2012; Tuuli \& Rowlinson, 2009; Y1ld1z et al., 2014) revealed that, there are numerous factors may impact employees' work performance, for instance, Job satisfaction, adoptability culture trait, social structure and psychological empowerment, employee work engagement, 
organization commitment, and leadership.

No doubt, leaders are committed to handle the demand of changes that arise from both the inside and outside organizations (Kouzes \& Posner, 2003). Multiple researchers and practitioners have stressed that leaders have to foster the acceptance of group goals and support group goals by encouraging subordinates to work together toward the achievement of their organizations' objectives (Bennis \& Nanus, 1985; Podsakoff et al., 1990).

Al Zefeiti and Mohamad (2015) suggest that effective leaders who have appropriate proficiency is needed in Omani organizations to deal with unpredictable events that may occasionally arise to increase their employees' performance. However, researchers argue that there remains a gap in leadership literature specifically in Middle East and North Africa (Mendenhall et al., 2008; Pless et al., 2011; Rao \& Abdul, 2015).

\section{Problem Statement}

Public organizations take a leading role in providing the best services to the community such as, health services, educational services, transportation and communications, and housing services. However if they want to be more successful, they need to response very quick to the fast movement in business domain by clearly encourage and foster subordinates' performance. Leadership is a crucial factor that may have considerable influence on work performance (Yukl, 1998). Therefore, public sector needs professional leaders to achieve organizational goals and objectives.

Previous research has devoted a great deal of attention to the relationship between leadership and work performance. The findings in this area, however, are not entirely consistent Therefore, the relationship between transformational leadership and work performance has attracted considerable interest from both practitioners and academics. Much of the interest on these variables is based on the outcomes of the previous researches which have revealed that these concepts may have an influence on the organizational goals (Khan et al., 2013; Yousef, 2000).

Yet, there is limited research investigating leadership within public sector organizations (AlKindy et al., 2016; Andersen, 2010; Fernandez et al., 2010; Teelken et al., 2012). Although incredible achievements were recorded by previous research, emphasizing the overall significance of transformational leadership in enhancing employees' work performances; there is also considerable reported research that calls for the needs to examine individual transformational leadership dimensions (Deinert et al., 2015). More specifically, there is a lack of studies that investigated the influence of transformational leadership behaviours demonstrated by Omani top managers level and how that impact employees' work performance. This study, therefore, is unique as it will help to address this issue in an effort to improve the understanding of the influence of transformational leadership on employees' work performance in Arabian Gulf Countries in general and in Omani setting in particular.

\section{Research Objective}

The aim of this paper is to investigate the influence of transformational leadership behaviours (dimensions) on Omani employees' contextual and task work performance. Based on the research objective stated, the following research question was addressed:

Q1. Do transformational leadership behaviours (dimensions) influence Omani public employees' contextual and task work performance?

\section{Literature Review}

\subsection{Transformational Leadership}

Transformational leadership is a familiar topic and it is the most outstanding issue in recent research and theories of leadership (Davidson, 2014; Palrecha et al., 2012; Taylor, 2014). Transformational leadership is the most frequently leadership research since the1970s (Bass, 1985; Bass et al., 1990) for increasing motivation (Charbonneau et al., 2001), performance (Barling et al., 2002), identification and high innovation (Bass et al., 2003; Scott, 2003) and managing organizations change (Bass and Riggio, 2006). Avolio et al. (1991) asserted that change and development are the two key elements necessary for any supervisor to become a transformational leader. Cacioppe (1997) argues that one of transformational leadership tasks is encouraging followers to adopt the vision of organisation as their own. Moreover, Burns (1978) reveals that transformational leadership inspires followers to enhance the level of their ethics, beliefs and coalition with the objectives of the organisation. Bass (1985); Shamir et al. (1993); and Sashkin (2004) perceive transformational leaders have the capability of inspiring and motivating followers to accomplish organizations' goals as their own. Transformational leaders make subordinates aware of the need for personal development and achievement and motivate them to work for the good of the organization (loyalty) rather than for their personal gain (George and 
Jones, 2008). Schepers et al. (2005) claimed that transformational leaders allow employees to think creatively, analyzed the problem from numerous angles and explored new and better solutions of the problem by using technology. Sarros et al. (2002) suggest that transformational leadership is an approach to leadership that based on encouraging others to perform more than what they originally thought possible. Leadership in Omani governmental organisations stresses on transformational leadership to enhance its performance. Podsakoff et al. (1990) have conceptualized transformational leadership behavior inventory (TLI) that consisting four key behaviours associated with transformational leaders such as, (1) core transformational leadership that consists articulating a vision, providing a role model, and fostering the acceptance of group goals, (2) providing individualized support, (3) high performance expectations, (4) intellectual stimulation. Nutt and Backoff (1993) argue that transformative leader who articulate a vision of change, encourages subordinates to participate in change process and support them to perform the predetermine change to achieve the desired objectives. Walumbwa et al. (2004) Leaders who provide an appropriate model can foster subordinates' loyalty and respect through desired behaviors. Pillai and Williams (2004) transformational leaders can encourage subordinates becoming more committed to their organization by promoting cooperation between subordinates, assisting them to work together, and getting them transcend their personal self-interest for the good of the group. Providing individualized support behaviours encourage subordinates to take on increasingly more responsibilities in order to develop to their full potential (Avolio \& Bass, 1995). Leaders who successfully behave intellectual stimulation, support change, persuade subordinates to be risk takers, and encourage them to think creatively and innovatively (Bass and Riggio, 2006). Transformational Leadership researches focus primarily on profit organisations such as private sector's organisations, but recently, many researchers have called for conducting transformational leadership research in public organisations (AlKindy et al., 2016; Andersen, 2010; Currie et al., 2009; Fernandez et al., 2010; Teelken et al., 2012; Vogel \& Masal, 2012).

\subsection{Work Performance}

Employees work performance is essential for any organization as it produces organizational overall performance (Berberoglu \& Secim, 2015). Work performance contains employees' behaviour relevant to production of goods and services (Hughes et al., 2008). Work performance is the whole goals and objectives that accomplished by a certain employee (Griffin, 2004). This performance results jointly from employee's effort and ability toward achieving organization's targets. Kocak (2006) defines performance as all activities that employees involve to fulfil their obligations toward achieving organizational goals and objectives. Indeed, all organizations whether they are, public, private, profitable or non-profitable have objectives and goals. Therefore, work performance is defined as behaviour that is related to accomplish organizations' goals and objectives (Campbell, 1990).

Performance is classified into two categories; that is task performance and contextual performance (Borman \& Motowidlo, 1993). Task performance comprises in-role responsibilities that differ from one job to the other. It refers to employees' direct involvement in practical duties in the process of achieving practical outcomes (Borman \& Motowidlo, 1997). Task performance refers to job-specific behaviours including core job responsibilities (Motowidlo \& Schmit, 1999). Task performance, also, represents labour activities that are specified by an official job description (Harrison et al., 2006).

Contextual performance represents extra-role activities that support the social and organizational environment (Borman \& Motowidlo, 1993). Contextual performance refers to employees' contribution in activities that shape working contexts (Borman \& Motowidlo, 1997). Contextual performance also refers to non-job specific behaviours such as, volunteering for extra work, following rules and regulations (Motowidlo \& Schmit, 1999). Contextual performance, also, represents voluntarily motivated work behaviours that go beyond an official job description but contribute to the psychological and social contexts around the job (Harrison et al., 2006).

Tan and Lau (2012) argued that the choice of performance measures used to assess employee work performance is critical due to its effect on employees' attitudes such as their perceptions of fairness, job satisfaction and organisational commitment.

Indeed, employees are required to do their ordinary duties in accordance to their formal job descriptions. Employees are also expected to expand their efforts to go beyond their formal job requirement and to exert extra effort to suggest creative and innovative ideas to enhance their organizational effectiveness (Law et al., 2010). Employees are required to coordinate with other and discuss organizational issues, exchange ideas, suggest and recommend ways to accomplish extraordinary work (Borman \& Motowidlo, 1993).

\subsection{The Influence of Transformational Leadership on Work Performance}

Enhancing employees' work performance to achieve organisational goals and objectives is an enduring challenge for most organizations. Researchers have conducted many studies to identify the factors responsible for 
increasing employees' work performance (Kamdar \& Van Dyne, 2007; Wang et al., 2005). Certainly, leadership is a crucial factor that may have considerable influence on work performance (Yukl, 1998). Practically, Sarmiento et al. (2007) state that all existing theories of leadership asserted that leaders can have a substantial influence on subordinates performance.

Indeed, supervisors play a bridge role between the organization and the employees, as they play an effective role in new employees' adaption to the organization. Transformational leaders have a considerable influence on employees' work performance by stimulate them to accept organizational goals and objectives as their own goals. Employees under supervision of transformational leaders, are able to have control and authority over their work, which in turn, enhance their work performance. Also, employees are encouraged to use their abilities and bring their own ideas to solve problems (Şahin et al., 2014). Researchers asserted that transformational leadership is one of the most influential factors motivating public employee performance (Paarlberg \& Lavigna, 2010; Park \& Rainey, 2008; Trottier et al., 2008; Wright et al., 2012).

Numerous of researchers postulate that the most influence of transformational leadership is the ability of leaders to lift ordinary people to extraordinary heights and cause subordinates to achieve more than they are expected to do, because they are expected to perform beyond the level of expectations (Bass, 1985; Yukl, 1989). However, Podsakoff et al. (1990) posit that the majority of researches that have been conducted to investigate the influence of transformational leadership on performance, in fact, focused on the impact of transformational leadership on in role performance instead of extra role performance. Therefore, transformational leaders are urged to focus on subordinate's extra-role performance (Bass \& Riggio, 2006) rather than in-role performance (Graham, 1988).

Certainly, previous research has devoted a great deal of attention to the relationship between leadership and work performance. The findings in this area, however, are not entirely consistent. In the last few years, other researchers, also, revealed that there is no linkage between transformational leadership and work performance (Chi et al., 2007; García-Morales et al., 2012).

Nevertheless, researchers point out that there is a positive relationship between transformational leadership and work performance (Bono \& Judge, 2003; Choi, 2006; Mullen \& Kelloway, 2010; Senthamil \& Palanichamy, 2011; Walumbwa et al., 2008; Wang \& Howell, 2012). Moreover, Podsakoff et al. (1996) suggest that individualized support, and fostering the acceptance of group goals have a significant effect on employee in-role performance.

Indeed, numerous of researchers have suggested that there is a positive association between leaders' consideration and subordinates' work performance (Farris \& Lim Jr, 1969; Greene, 1975; Lowin \& Craig, 1968). Furthermore, MacKenzie et al. (2001) state that there is a direct relationship between transformational leadership dimensions (e.g. individualized support and intellectual stimulation) and performance. They further state that some aspects of transformational leadership are related both directly and indirectly to performance while high performance expectations were not related either directly or indirectly to performance.

Deconinck and Beth (2013) have examined the relationship between transformational leadership and performance. Transformational leadership behaviour were measured using the transformational leadership behaviour Inventory developed by Podsakoff et al. (1990). The results show that two measures of transformational leadership, individualized support and core transformational behaviour that consists articulating a clear vision, providing an appropriate model, and fostering the acceptance of group goals were related positively to increased performance by the sales force. Also, they suggest that a sales manager who articulates a vision and serves as a role model for salespeople can influence their performance. However, the result exhibited that setting high performance expectation and stimulating salespeople intellectually do not lead to increased performance.

Therefore, the contradictory research findings in previous researches guided this study to investigate the transformational leadership behaviours influence on Omani employees' work performance, as shown in Figure 1, which led to the design research hypotheses.

H1: Core transformational leadership has a direct impact on task performance

$\mathrm{H} 2$ : Providing individualized support has a direct impact on task performance

H3: Intellectual stimulation has a direct impact on task performance

H4: Setting high performance expectations has a direct impact on task performance

H5: Core transformational leadership has a direct impact on contextual performance

H6: Providing individualized support has a direct impact on contextual performance 
H7: Intellectual stimulation has a direct impact on contextual performance

H8: Setting high performance expectations has a direct impact on contextual performance

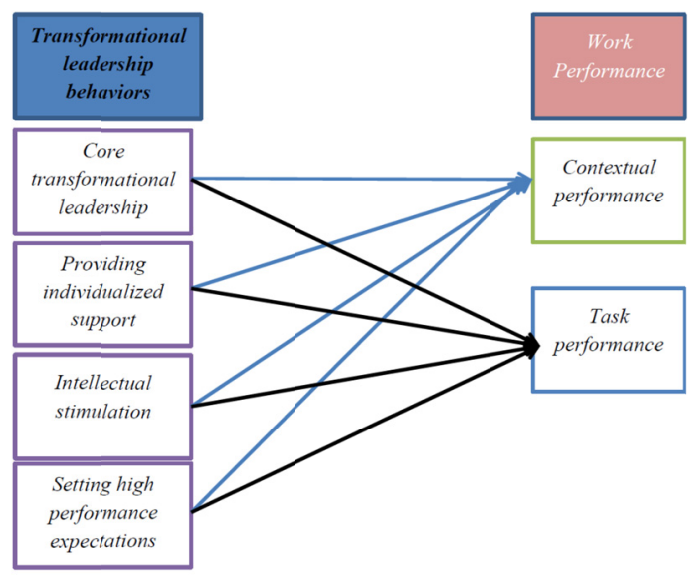

Figure 1: Research Framework

\section{Research Methodology}

\subsection{Sample and Data Collection}

This research attempted to describe the impact of transformational leadership behaviors on work performance. The quantitative data was collected through survey instrument out of (500) questionnaires were distributed with (360) returning. Of the (360) that returned, (25) questionnaires were rejected, due to incomplete and defective response given by the respondents, resulting in (335) usable questionnaires yielding a response rate of $93 \%$. Details are demonstrated in Table 1.

The stratified sample sampling was used in this study and the sample size has been chosen according to the population of Omani public civil services organizations that applying Civil Service law and the percentage of the middle managers in each organizations then the sample was selected randomly.

The data were then analyzed using Statistical Package for Social Sciences (SPSS) and AMOS. The questionnaire applying five-point Likert scale.

Table 1. Response Rate of the Questionnaire

\begin{tabular}{ccccc}
\hline Survey method & & Questionnaire & Frequency & Percentage (\%) \\
\hline Paper & Return & Returned & 360 & 72 \\
Survey & Rate & Unreturned & 140 & 28 \\
& Usable Rate & Useable and Non Defective Responses & 335 & 93 \\
& & Defective Response and Rejected & 25 & 7 \\
\hline
\end{tabular}

\subsection{Transformational Leadership Dimensions}

Transformational leadership behaviours (TLB) was measured using scale developed by Podsakoff et al. (1990). The scale used four dimensions to measure the TLB. The dimensions are core transformational leadership (Core), providing individualized support (PIS), intellectual stimulation (IS), and setting high performance expectations (SHPE) (Deconinck \& Beth, 2013; MacKenzie et al., 2001; Schwepker Jr \& Good, 2013). To describe their direct supervisor's leadership behavior, participants responded to 29 items, twenty three questions adapted from Podsakoff et al. (1990), and six questions were developed for this study, an example of measurement is, my leader gets the group to work together for the same goal, making use of 5-point rating scales with $1=$ Strongly disagree and $5=$ Strongly agree.

\subsection{Work Performance Subscales}

Work performance instrument is composed of two subscales corresponding to different types of work performance; (a) task performance (WPR) (O'Reilly \& Chatman, 1986; Williams \& Anderson, 1991), and (b) contextual performance (WPE) (Brockner et al., 1992; May et al., 2002). To describe their work performance, participants responded to 12 items, making use of 5-point rating scales with $1=$ Strongly disagree and $5=$ Strongly agree. 


\section{Result}

As factor analysis and structural equation modeling both necessitate variables to be normality distributed, it was crucial to test normality in this research to confirm whether that a sample of observation comes from a normal distribution (Hair et al., 1995; Kline, 2011; Tabachnick \& Fidell, 2001). Utilizing AMOS, an examination of both skewness and kurtosis showed that the absolute values were within the recommended levels suggesting univariate normality. However, there was one items (WP.Role6r) in the work performance construct which does not have normal distribution. The work performance construct consists of twelve items. Since only one item of all the twelve items does not meet the normality assumption, it appears that this situation should not be a major concern.

In the measurement model, as shown in Figure 3, all the items were tested to check, whether all the confirmed items of constructs, significantly contribute as a whole in the proposed model of the current study. Table 2 indicated that, the default model required some adjustments, in order to achieve the required model fitness. First step was to remove those items, showing factor loading less than 0.50 (Hair et al., 2010). Initial results signalled a weak model fit and item loadings of the constructs. Table 2 shows the results of the initial factor loadings of items IAV6, WP.Role5, WP.Role6, WP.Extra2 and WP.Extra6 were removed from the further analysis due to low value of factor loading, rest of the items were retained.

Table 2. Factor loadings

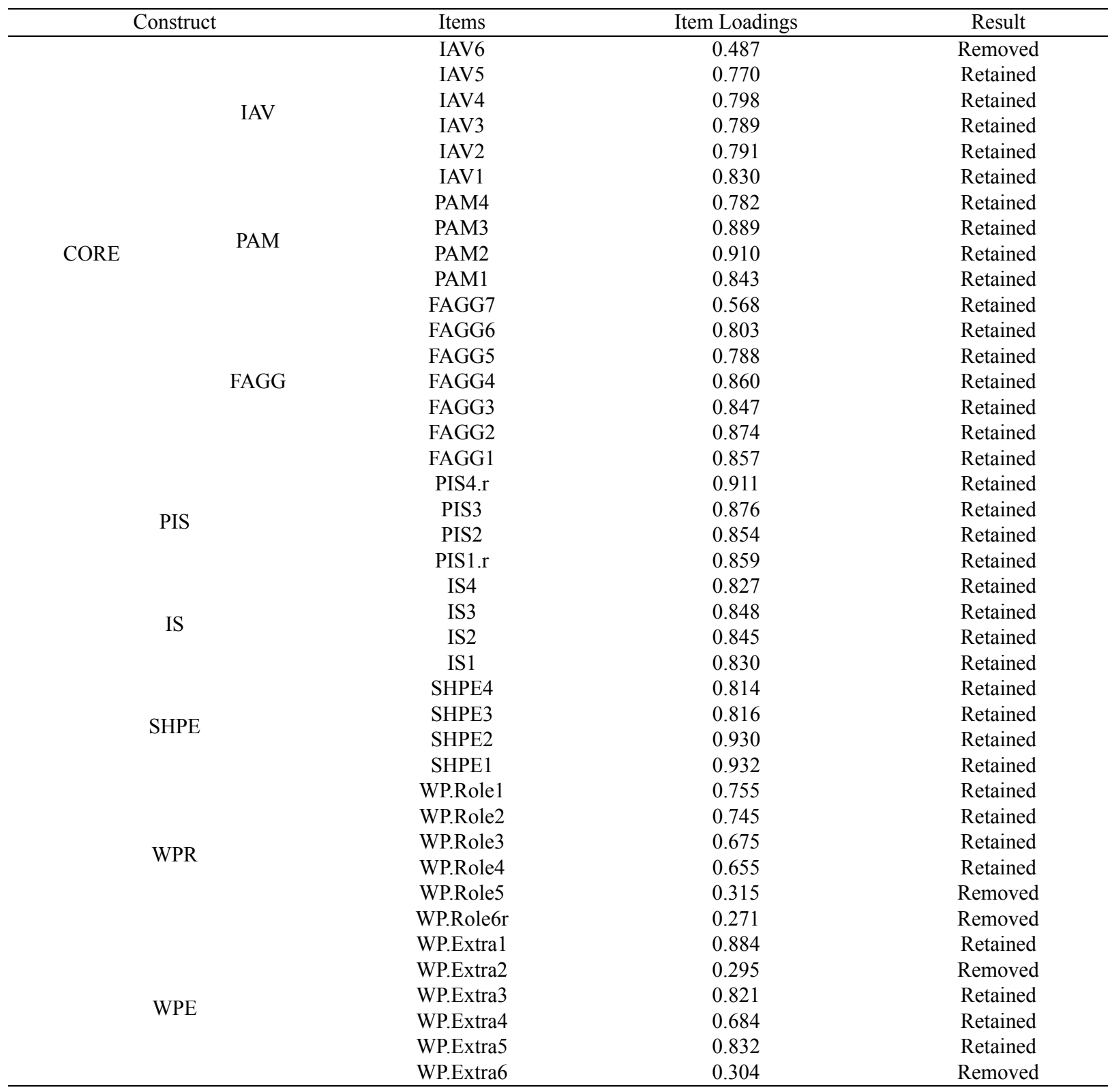




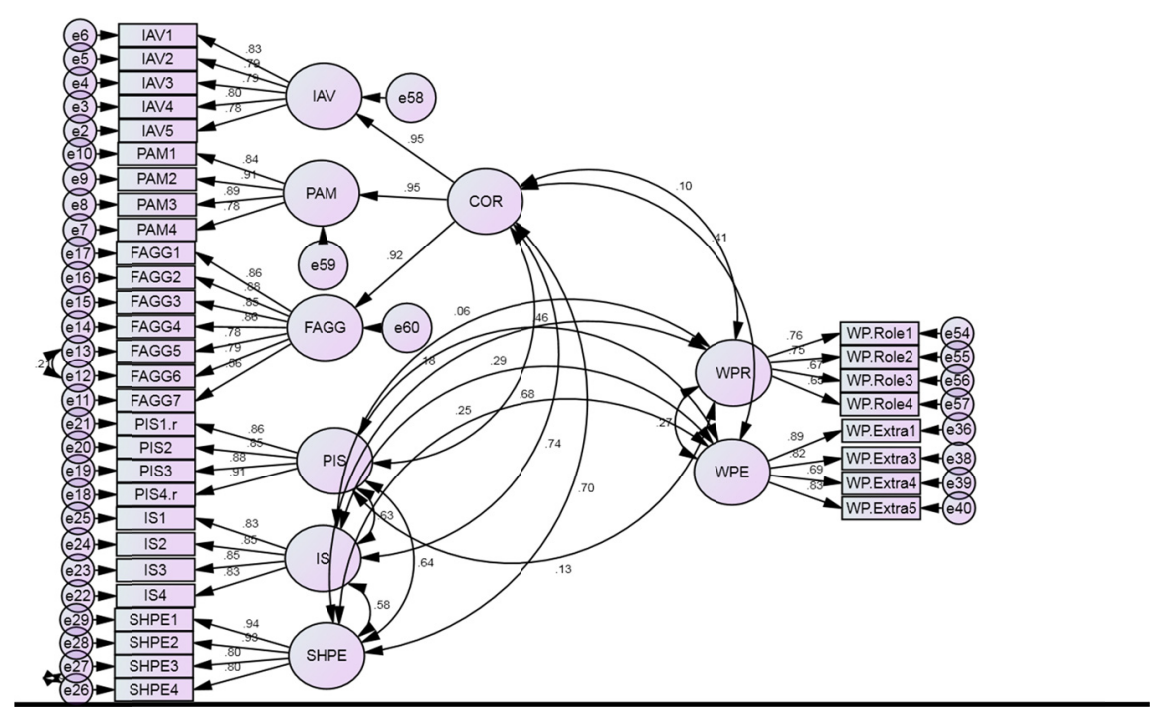

Figure 2. Measurement model

The values for goodness of fit was Chi-Square=9.93; $(\mathrm{DF}=2)$, Relative Chi-Sq $(<5.0)=4.98, \mathrm{CFI}=0.996$, TLI= 0.931, NFI $=0.995, \mathrm{GFI}=0.994$. RMSEA $=0.041$. These values showed that measurement model achieved good model fitness. The last step for achieving model fitness was to correlate error terms of the items having modification indices above than 40 .

Convergent validity determines the amount of correlation, among the measures of the same concept (Arbuckle, 2011; Hair et al., 2010; Rasli, 2006). The convergent validity is achieved when all items in a measurement model are statistically significant. Awang (2014) recommends that the value of average variance extracted (AVE) should be equal to or greater than 0.50 to validate using a construct. Thus, as shown in Table 3 the convergent validity for this scale was established because each factor loading constructs was more than .50 (Awang, 2014).

Table 3. Convergent Validity

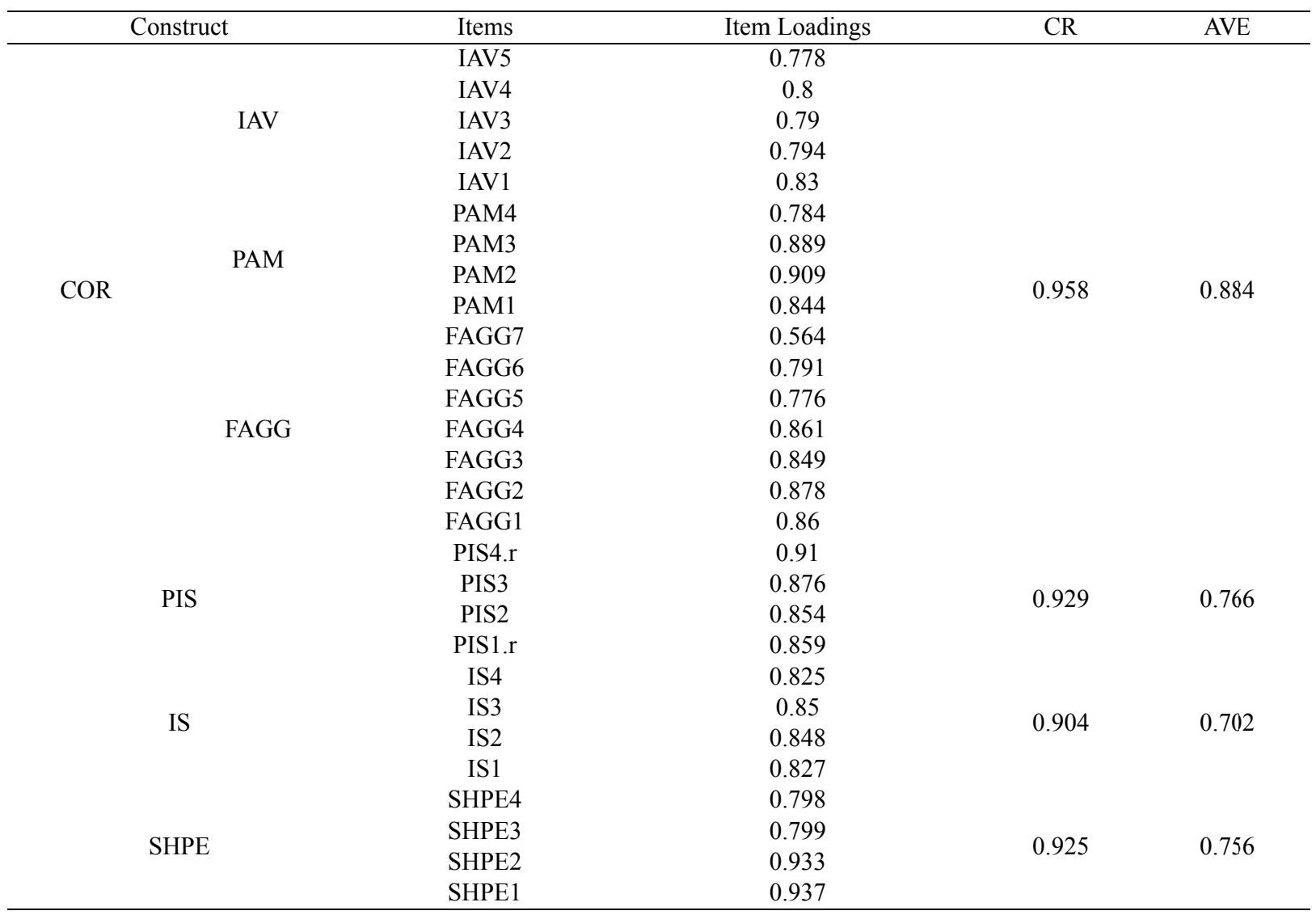




\begin{tabular}{ccccc}
\hline & WP.Role1 & 0.805 & & \\
WP.Role2 & 0.758 & 0.801 & 0.503 \\
WP.Role3 & 0.752 & & \\
WP.Role4 & 0.758 & & \\
WP.Extra1 & 0.754 & & 0.884 \\
WPE & WP.Extra2 & 0.753 & 0.658 \\
& WP.Extra3 & 0.674 & & \\
& WP.Extra4 & 0.65 & & \\
\hline
\end{tabular}

The measurement model should be free from redundant items to achieve discriminant validity (Awang, 2014). The inter-construct correlation of each variable and square root of average variance extraction indicate that all the constructs have adequate discriminant validity, as the square root of average variance extracted is greater than inter-construct correlation of each variable and also the values of inter construct are less than .85 (Awang, 2014). Thus, these results provide sufficient evidence of discriminant validity of the constructs (see table 4).

Table 4. Discriminant Validity

\begin{tabular}{ccccccc}
\hline Constructs & IS & PIS & SHPE & WPR & WPE & COR \\
\hline IS & 0.838 & & & & & \\
PIS & 0.633 & 0.875 & & & & \\
SHPE & 0.582 & 0.635 & 0.869 & & & \\
WPR & 0.060 & 0.134 & 0.181 & 0.709 & 0.811 & \\
WPE & 0.289 & 0.461 & 0.251 & 0.266 & 0.414 & 0.940 \\
COR & 0.741 & 0.682 & 0.703 & 0.099 & 0.414 \\
\hline
\end{tabular}

This study hypothesized that, four behaviours of transformational leadership (Core transformational leadership, Providing Individual Support, Intellectual Stimulation, setting high performance expectation) have a significant effect on work performance (Contextual and Task) (H1 and H8). Figure 2 illustrates results of the path model.

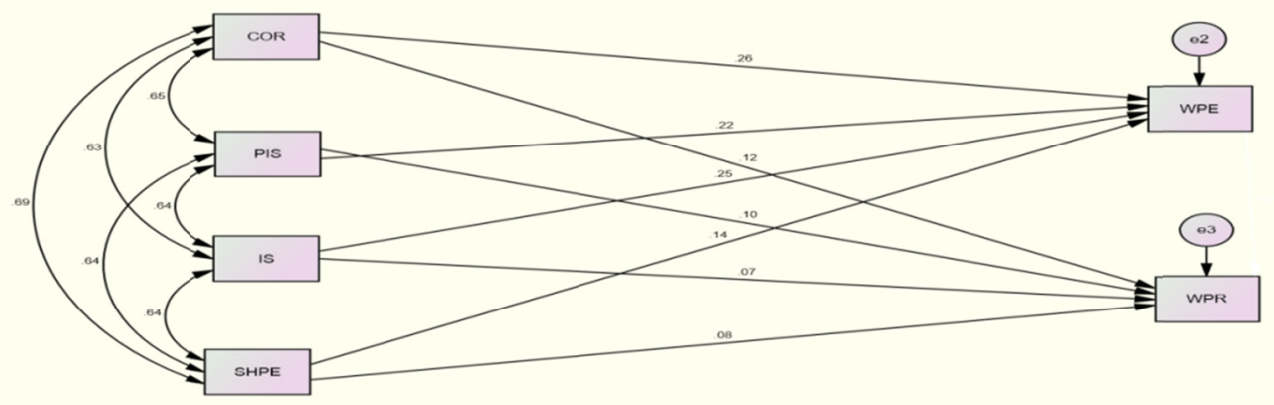

Figure 3. Transformational Leadership- Work Performance

The researcher proposed the hypothesis H1: Core transformational leadership has a direct impact on task performance. Results as shown in table 4 indicated that the path coefficient value is 0.134 ; critical ratio is 2.63 and $\mathrm{p}$ value 0.009 . This indicates the significance of the direct relationship between Core and WPR. The researcher proposed the hypothesis H2: providing individualized support has a direct impact on task performance. Results as shown in table 4 indicated that the path coefficient value is 0.113 ; critical ratio is 2.33 and $p$ value 0.020 . This indicates the significance of the direct relationship between PIS and WPR. The researcher proposed the hypothesis H3: intellectual stimulation has a direct impact on task performance. Results as shown in table 4 indicated that the path coefficient value is 0.086 ; critical ratio is 1.72 and $p$ value 0.086 . This indicates there is insignificant direct relationship between IS and WPR. The researcher proposed the hypothesis H4: setting high performance expectations has a direct impact on task performance. Results as shown in table 4 indicated that the path coefficient value is 0.091 ; critical ratio is 1.84 and $\mathrm{p}$ value 0.066 . This indicates there is insignificant direct relationship between SHPE and WPR.

The researcher proposed the hypothesis H5: Core transformational leadership has a direct impact on contextual performance. Results as shown in table 4 indicated that the path coefficient value is 0.27 ; critical ratio is 4.57 and $\mathrm{p}$ value 0.000 . This indicates the significance of the direct relationship between Core and WPE. The researcher proposed the hypothesis H6: providing individualized support has a direct impact on contextual 
performance. Results as shown in Table 5 indicated that the path coefficient value is 0.24 ; critical ratio is 4.17 and $\mathrm{p}$ value 0.000 . This indicates the significance of the direct relationship between PIS and WPE. The researcher proposed the hypothesis H7: intellectual stimulation has a direct impact on contextual performance. Results as shown in table 4 indicated that the path coefficient value is 0.269 ; critical ratio is 4.68 and $p$ value 0.000. This indicates the significance of the direct relationship between IS and WPE. The researcher proposed the hypothesis H8: setting high performance expectations has a direct impact on contextual performance. Results as shown in table 4 indicated that the path coefficient value is 0.14 ; critical ratio is 2.48 and $\mathrm{p}$ value 0.013. This indicates the significance of the direct relationship between SHPE and WPE.

Table 5. Testing Hypothesis Using Standardized Estimates (Hypothesized Model)

\begin{tabular}{|c|c|c|c|c|c|c|c|c|}
\hline \multicolumn{4}{|c|}{ Hypothesized path } & \multirow{2}{*}{$\begin{array}{c}\text { B } \\
.134\end{array}$} & \multirow{2}{*}{$\begin{array}{l}\text { S.E. } \\
.051\end{array}$} & \multirow{2}{*}{\begin{tabular}{|l} 
C.R. \\
2.631
\end{tabular}} & \multirow{2}{*}{$\begin{array}{c}\mathrm{P} \\
.009\end{array}$} & \multirow{2}{*}{$\begin{array}{c}\text { Supported } \\
\text { Yes }\end{array}$} \\
\hline H1 & Core & $\rightarrow$ & WPR & & & & & \\
\hline $\mathrm{H} 2$ & PIS & $\rightarrow$ & WPR & .113 & .049 & 2.326 & .020 & Yes \\
\hline $\mathrm{H} 3$ & IS & $\rightarrow$ & WPR & .086 & .050 & 1.717 & .086 & No \\
\hline $\mathrm{H} 4$ & SHPE & $\rightarrow$ & WPR & .091 & .049 & 1.836 & .066 & No \\
\hline H5 & Core & $\rightarrow$ & WPE & .270 & .059 & 4.574 & .000 & Yes \\
\hline H6 & PIS & $\rightarrow$ & WPE & .236 & .057 & 4.166 & .000 & Yes \\
\hline $\mathrm{H} 7$ & IS & $\rightarrow$ & WPE & .269 & .058 & 4.676 & .000 & Yes \\
\hline H8 & SHPE & $\rightarrow$ & WPE & .144 & .058 & 2.475 & .013 & Yes \\
\hline
\end{tabular}

\section{Research Contributions and Recommendation for Future Study}

This study is expected to provide additional insight into the influence of transformational leadership behaviours, on work performance, which should contribute to the future development of this line of research, specifically, in a non-western country. It expands the generalizability of transformational leadership behaviours beyond the limits of US-EU contexts, as this research has been conducted in a developing country e.g. Omani governmental organizations and thus samples from several governmental sectors, such as, finance, manpower, education, tourism, and health were examined, thereby answering the call for research on leadership in different cultures (Gardner et al., 2010; Hartog and Dickson, 2012; Kuchinke, 1999; Pieterse et al., 2010). Accordingly, the results of this study will strengthen the existing knowledge on the effectiveness of US-based transformational leadership behaviours in developing countries.

Moreover, from a practical viewpoint, Omani public organizations are advised to invest more in transformational leadership training and in the selection of top level managers with these leadership behaviors to increase their employees' work performance. Thus, the current research should attract public sector leaders' attention to the importance of adopting the appropriate transformational leadership behaviours. These could result in enhancing employees' employees' work performance, consequently providing quick and good services to citizens.

The findings of the present research are limited to the middle-level managers in the Omani public civil service organizations and thus cannot be generalized to the Omani context as a whole. Future longitudinal and experimental research that covers both Omani public and private organizations would help confirm the causal paths investigated in the current research.

\section{Limitation}

It is imperative to note that since this research examined the transformational leadership behaviours of top-level managers and their impact on middle-managers' work performance within public service organizations. It limits the nature of this kind of highly sensitive information. The extraction of this kind of highly sensitive information may be less accurate due to the reluctance divulge. Additional research, preferably qualitative research, should now be conducted to compensate for any lack of data in this current study

\section{Conclusion}

The purpose of this study is to examined the influence of each transformational leadership components on employee work performance. Transformational leadership dimensions are positively related to employee work performance. This indicates that transformational leadership components emerged as the contributing factor and play important roles in enhancing employees' work performance. Moreover, the need to extend the research on the influence of separate dimensions of transformational leadership to gain a deeper understanding of the nature and the antecedents of these leadership behaviours, rather than the usual practice of combining them into one overall scale as reported in the literature (Deinert et al., 2015; Van Knippenberg and Sitkin, 2013) is met in this 
research, by examining the influence of individual transformational leadership dimensions on contextual and task performance. There are limited studies that have examined the relationships between transformational leadership dimensions and contextual and task performance generally and with respect to Omani public service organizations. One of the objectives of this research is to examine these relationships, by investigating the direct effects between them. It is therefore demonstrated through the findings from this research, that a significant relationship exists between some of transformational leadership dimensions and some of work performance dimensions. Indeed, this research has empirically investigated the conceptual model and demonstrated that all transformational leadership behaviours such as core transformational leadership and providing individualized support, intellectual stimulation and setting high performance have a positive direct influence on employees' contextual work performance and two of transformational leadership behaviours such as core transformational leadership and providing individualized support, have a direct influence on employees' task performance. Thus, the results of this research emphasize that transformational leadership dimensions have different impacts on employees' work performance.

\section{References}

Akdere, M. (2006). Quality Management through Human Resources: An Integrated Approach to Performance Improvement. The Business Review, Cambridge, 5(2), 233-238.

Al Zefeiti, S. M. B., \& Mohamad, N. A. (2015). Methodological considerations in studying transformational leadership and its outcomes. International Journal of Engineering Business Management, 7(1), 1-11.

Ali, N., Jan, S., Ali, A., \& Tariq, M. (2014). Transformational and Transactional Leadership as Predictors of Job Satisfaction, Commitment, Perceived Performance and Turnover Intention (Empirical Evidence from Malakand Division, Pakistan). Life Science Journal, 11(5), 48-53.

AlKindy, A. M., Shah, I. M., \& Jusoh, A. (2016). The Impact of Transformational Leadership Behaviors on Work Performance of Omani Civil Service Agencies. Asian Social Science, 12(3), 152.

Andersen, J. A. (2010). Public versus Private Managers: How Public and Private Managers Differ in Leadership Behavior. Public Administration Review, 70(1), 131-141.

Arbuckle, J. L. (2011). IBM SPSS Amos 20 user's guide. Amos Development Corporation, : SPSS Inc.

Avolio, B. J., \& Bass, B. M. (1995). Individual consideration viewed at multiple levels of analysis: A multi-level framework for examining the diffusion of transformational leadership. The Leadership Quarterly, 6(2), 199-218.

Avolio, B. J., Waldman, D. A., \& Yammarino, F. J. (1991). Leading in the 1990s: The four I's of transformational leadership. Journal of European industrial training, 15(4).

Awang, Z. (2014). A handbook on structural equation modelling for academicians and practitioners. Bandar Baru Bangi, Selangor: MPWS Rich Resources.

Barling, J., Loughlin, C., \& Kelloway, E. K. (2002). Development and test of a model linking safety-specific transformational leadership and occupational safety. Journal of Applied Psychology, 87(3), 488.

Bass, B. M. (1985). leadership and performance beyond expectations. New York: The Free Press, 256.

Bass, B. M., Avolio, B. J., Jung, D. I., \& Berson, Y. (2003). Predicting unit performance by assessing transformational and transactional leadership. Journal of applied psychology, 88(2), 207.

Bass, B. M., Avolio, B. J., \& Pointon, J. (1990). The implications of transactional and transformational leadership for individual, team, and organizational development.

Bass, B. M., \& Riggio, R. E. (2006). Transformational leadership: Mahwah, NJ: Lawrence Erlbaum Associates.

Bennis, W., \& Nanus, B. (1985). Leadership: The strategies for taking charge. New York.

Berberoglu, A., \& Secim, H. (2015). Organizational Commitment and Perceived Organizational Performance Among Health Care Professionals: Empirical Evidence From A Private Hospital in Northern Cyprus. Journal of Economics and Behavioral Studies, 7(1), 64-71.

Bono, J. E., \& Judge, T. A. (2003). Self-concordance at work: Toward understanding the motivational effects of transformational leaders. Academy of Management Journal, 46(5), 554-571.

Borman, W. C., \& Motowidlo, S. (1993). Expanding the criterion domain to include elements of contextual performance. Personnel selection in organizations; San Francisco: Jossey-Bass, 71.

Borman, W. C., \& Motowidlo, S. J. (1997). Task performance and contextual performance: The meaning for 
personnel selection research. Human performance, 10(2), 99-109.

Brockner, J., Tyler, T. R., \& Cooper-Schneider, R. (1992). The influence of prior commitment to an institution on reactions to perceived unfairness: The higher they are, the harder they fall. Administrative Science Quarterly, $37(2), 241-261$

Burns, J. M. (1978). Leadership. New York: Harper \& Row.

Cacioppe, R. (1997). Leadership moment by moment! Leadership \& Organization Development Journal, 18(7), 335-345.

Campbell, J. P. (1990). An overview of the army selection and classification project (Project A). Personnel Psychology, 43(2), 231-239.

Charbonneau, D., Barling, J., \& Kelloway, E. K. (2001). Transformational Leadership and Sports Performance: The Mediating Role of Intrinsic Motivation1. Journal of Applied Social Psychology, 31(7), 1521-1534.

Chi, H.-K., Tsai, H.-P., \& Chang, P.-F. (2007). Investigating the relationship among leadership styles, emotional intelligence and organization commitment on job performance: A study of salespeople in Thailand. The Journal of Human Resource and Adult Learning, 3(2), 199-212.

Choi, J. (2006). A motivational theory of charismatic leadership: Envisioning, empathy, and empowerment. Journal of Leadership \& Organizational Studies, 13(1), 24-43.

Currie, G., Lockett, A., \& Suhomlinova, O. (2009). Leadership and institutional change in the public sector: The case of secondary schools in England. The Leadership Quarterly, 20(5), 664-679.

Davidson, B. A. (2014). Examining the relationship between non-cognitive skills and leadership: The influence of hope and grit on transformational leadership behavior. Unpublished Ed.D., University of Kansas, Ann Arbor.

Deconinck, J., \& Beth, M. (2013). The Relationship Among Transformational Leadership, Supervisory Trust, Performance and Turnover Intentions. GSTF Business Review (GBR), 2(3), 205-211.

Deinert, A., Homan, A. C., Boer, D., Voelpel, S. C., \& Gutermann, D. (2015). Transformational leadership sub-dimensions and their link to leaders' personality and performance. The Leadership Quarterly, 26(6), 1095-1120.

Dvir, T., Eden, D., Avolio, B. J., \& Shamir, B. (2002). Impact of transformational leadership on follower development and performance: A field experiment. Academy of management journal, 45(4), 735-744.

Farris, G. F., \& Lim Jr, F. G. (1969). Effects of performance on leadership, cohesiveness, influence, satisfaction, and subsequent performance. Journal of Applied Psychology, 53(6), 490.

Fernandez, S., Cho, Y. J., \& Perry, J. L. (2010). Exploring the link between integrated leadership and public sector performance. The Leadership Quarterly, 21(2), 308-323.

García-Morales, V. J., Jiménez-Barrionuevo, M. M., \& Gutiérrez-Gutiérrez, L. (2012). Transformational leadership influence on organizational performance through organizational learning and innovation. Journal of Business Research, 65(7), 1040-1050.

Gardner, W. L., Lowe, K. B., Moss, T. W., Mahoney, K. T., \& Cogliser, C. C. (2010). Scholarly leadership of the study of leadership: a review of the leadership quarterly's second decade, 2000-2009. The Leadership Quarterly, 21(6), 922-958.

George, J. M., \& Jones, G. R. (2008). Understanding and managing organizational behavior (5th ed.): Upper Saddle River, NJ: Pearson Prentice Hall.

Givens, R. J. (2011). The role of psychological empowerment and value congruence in mediating the impact of transformational leadership on follower commitment in American churches. International Journal of Leadership Studies, 6(2), 188-214.

Graham, J. W. (1988). Chapter 3 commentary: Transformational leadership: Fostering follower autonomy, not automatic followership. In J.G. Hunt, B.R. Baliga, H.P. Dachler, SC C.A. Schriesheim (Eds.),. Emerging leadership vistas, 73-79, Lexington, MA: Lexington Books.

Greene, C. N. (1975). The reciprocal nature of influence between leader and subordinate. Journal of Applied Psychology, 60, 187-193.

Griffin, J. (2004). Relation of principal transformational leadership to school staff job satisfaction, staff turnover, 
and school performance. Journal of Educational Administration, 42(3), 333-356.

Hair, J. F., Anderson, R. E., Tatham, R. L., \& Black, W. C. (1995). Multivariate Data Analysis with Readings (4th ed.). Englewood Cliffs, NJ: Prentice Hall.

Hair, J. J. F., Black, W. C., Babin, B. J., \& Anderson, R. E. (2010). Multivariate data analysis: A global perspective. Upper Saddle River, New Jersey: Pearson Education.

Hamel, G., \& Prahalad, C. K. (1990). The core competencies of the corporation. Harvard Business Review, 79-91.

Harrison, D. A., Newman, D. A., \& Roth, P. L. (2006). How important are job attitudes? Meta-analytic comparisons of integrative behavioral outcomes and time sequences. Academy of Management Journal, 49(2), 305-325.

Hartog, D. D. N., \& Dickson, M. (2012). Leadership and culture. In D. Day \& J. Antonakis (Ed.), The nature of leadership (pp. 393-436): Thousand Oaks, CA: Sage Publications Inc.

House, R. J., \& Shamir, B. (1993). Toward the integration of transformational, charismatic, and visionary theories, Chemers MM, Ayman R., Leadership theory and research: Perspectives and directions, (Vol. 81, pp. 107): Academic Press, San Diego, CA.

Hughes, R. L., Ginnet, R. C., \& Curphy, G. L. (2008). Charisma and transformational leadership. leadership: enhancing lessons from experiences: Boston: Irwin/McGraw Hill.

Joo, B.-K. B., \& Lim, T. (2013). Transformational leadership and career satisfaction: the mediating role of psychological empowerment. Journal of Leadership \& Organizational Studies, 1548051813484359.

Jose, G., \& Mampilly, S. R. (2014). Psychological Empowerment as a Predictor of Employee Engagement: An Empirical Attestation. Global Business Review, 15(1), 93-104.

Kamdar, D., \& Van Dyne, L. (2007). The joint effects of personality and workplace social exchange relationships in predicting task performance and citizenship performance. Journal of Applied Psychology, 92(5), 12861298.

Khan, Z., Khan, S., \& Shahzad, S. (2013). Moderating Role of Procedural Justice and Empowerment in Transformational Leadership with its impact on Organizational Commitment. International Review of Management and Business Research, 2(3), 847-852.

Kline, R. B. (2011). Principles and practice of structural equation modeling (3rd ed.). New York London: Guilford press.

Kocak, R. (2006). The validity and reliability of the teachers' performance evaluation scale. Educational Sciences: Theory \& Practice, 6(3), 799-808.

Kouzes, J. M., \& Posner, B. Z. (2003). The leadership challenge: San Francisco: Jossey Bass.

Kuchinke, K. P. (1999). Leadership and culture: Work-related values and leadership styles among one company's US and German telecommunication employees. Human Resource Development Quarterly, 10(2), 135-154.

Law, K. S., Hui, W., \& Chun, H. (2010). Currencies of exchange and global LMX: How they affect employee task performance and extra-role performance. Asia Pacific Journal of Management, 27(4), 625-646.

Lee, C.-S., Lee, W., \& Kim, J. (2007). Effects of Transformational Leadership and Self-leadership on Innovative Behaviors: Mediating Roles of Empowerment*. International Area Studies Review, 10(2), 163-176.

Lowin, A., \& Craig, J. R. (1968). The influence of level of performance on managerial style: An experimental object-lesson in the ambiguity of correlational data. Organizational Behavior and Human Performance, $3(4), 440-458$.

Macey, W. H., \& Schneider, B. (2008). The meaning of employee engagement. Industrial and organizational Psychology, 1(1), 3-30.

MacKenzie, S. B., Podsakoff, P. M., \& Rich, G. A. (2001). Transformational and transactional leadership and salesperson performance. Journal of the Academy of Marketing Science, 29(2), 115-134.

Manaf, A. H. A., \& Latif, L. A. (2014). Transformational Leadership and Job Performance of SMEs Technical Personnel: The Adaptability Cultural Approach as Mediator. Mediterranean Journal of Social Sciences, 5(20), 648.

May, T. Y.-M., Korczynski, M., \& Frenkel, S. J. (2002). Oranizational and occupatinal commitment: Knowledge 
workers in large corporations. Journal of management Studies, 39(6), 775-801.

Mendenhall, M. E., Osland, J. S., Bird, A., Oddou, G., \& Maznevski, M. (2008). Global Leadership: Research, Practice, and Development. London/New York, NY: Routledge.

Mendonca, M. (2001). Preparing for ethical leadership in organizations. Canadian Journal of Administrative Sciences/Revue Canadienne des Sciences de l'Administration, 18(4), 266-276.

Miao, Q., Newman, A., \& Lamb, P. (2012). Transformational leadership and the work outcomes of Chinese migrant workers: The mediating effects of identification with leader. Leadership, 8(4), 377-395.

Ministry of Civil Service. (2012). Retrieved. from http://www.mocs.gov.om/tabid/533/Default.aspx , 13.9.2012.

Moss, S. A., \& Ritossa, D. A. (2007). The impact of goal orientation on the association between leadership style and follower performance, creativity and work attitudes. Leadership, 3(4), 433-456.

Motowidlo, S. J., \& Schmit, M. J. (1999). Performance assessment in unique jobs, In D. R. Ilgen \& E. D. Pulakos (Eds.) (pp. 56-86). The changing nature of job performance: Implications for staffing, motivation, and development: San Francisco: Jossey-Bass.

Mullen, J., \& Kelloway, E. K. (2010). Occupational health and safety leadership, in Quick, J.C. \& Tetrick, L.E. (Eds), Handbook of Occupational Health Psychology (2nd ed., pp. 357-372): American Psychological Association, Washington, DC.

Nusair, N., Ababneh, R., \& Bae, Y. K. (2012). The impact of transformational leadership style on innovation as perceived by public employees in Jordan. International Journal of Commerce and Management, 22(3), $182-201$.

Nutt, P. C., \& Backoff, R. W. (1993). Transforming public organizations with strategic management and strategic leadership. Journal of Management, 19(2), 299-347.

O'Reilly, C. A., \& Chatman, J. (1986). Organizational commitment and psychological attachment: The effects of compliance, identification, and internalization on prosocial behavior. Journal of applied psychology, 71(3), 492-499.

Paarlberg, L. E., \& Lavigna, B. (2010). Transformational leadership and public service motivation: Driving individual and organizational performance. Public administration review, 70(5), 710-718.

Palrecha, R., Spangler, W. D., \& Yammarino, F. J. (2012). A comparative study of three leadership approaches in India. The Leadership Quarterly, 23(1), 146-162.

Park, S. M., \& Rainey, H. G. (2008). Leadership and public service motivation in US federal agencies. International public management journal, 11(1), 109-142.

Pieterse, A. N., Van Knippenberg, D., Schippers, M., \& Stam, D. (2010). Transformational and transactional leadership and innovative behavior: The moderating role of psychological empowerment. Journal of Organizational Behavior, 31(4), 609-623.

Pillai, R., \& Williams, E. A. (2004). Transformational leadership, self-efficacy, group cohesiveness, commitment, and performance. Journal of organizational change management, 17(2), 144-159.

Pless, N. M., Maak, T., \& Stahl, G. K. (2011). Developing responsible global leaders through international service-learning programs: The Ulysses experience. Academy of Management Learning \& Education, 10(2), 237-260.

Podsakoff, P. M., MacKenzie, S. B., \& Bommer, W. H. (1996). Meta-analysis of the relationships between Kerr and Jermier's substitutes for leadership and employee job attitudes, role perceptions, and performance. Journal of Applied Psychology, 81(4), 380-399.

Podsakoff, P. M., MacKenzie, S. B., Moorman, R. H., \& Fetter, R. (1990). Transformational leader behaviors and their effects on followers' trust in leader, satisfaction, and organizational citizenship behaviors. The Leadership Quarterly, 1(2), 107-142.

Rao, A. S., \& Abdul, W. K. (2015). Impact of transformational leadership on team performance: an empirical study in UAE. Measuring Business Excellence, 19(4), 30-56.

Rasli, A. (2006). Data Analysis and Interpretation-A Handbook for Postgraduate Social Scientists (+ CD): Penerbit UTM.

Şahin, D. R., Çubuk, D., \& Uslu, T. (2014). The Effect of Organizational Support, Transformational Leadership, 
Personnel Empowerment, Work Engagement, Performance and Demographical Variables on the Factors of Psychological Capital. EMAJ: Emerging Markets Journal, 3(3), 1-17.

Sarmiento, R., Beale, J., \& Knowles, G. (2007). Determinants of performance amongst shop-floor employees: A preliminary investigation. Management Research News, 30(12), 915-927.

Sarros, J. C., Gray, J. H., \& Densten, I. L. (2002). Leadership and its impact on organizational culture. Journal of International Business Studies, 10(2), 1-26.

Sashkin, M. (2004). Transformational leadership approaches: A review and synthesis, In J. Antonakis, A. T. Cianciolo, \& R. J. Sternberg (Eds.). The nature of leadership, (pp. 171-196). Thousand Oaks: Sage Publications.

Schepers, J., Wetzels, M., \& de Ruyter, K. (2005). Leadership styles in technology acceptance: do followers practice what leaders preach? Managing Service Quality, 15(6), 496-508.

Schwepker Jr, C. H., \& Good, D. J. (2013). Improving salespeople's trust in the organization, moral judgment and performance through transformational leadership. Journal of Business \& Industrial Marketing, 28(7), 535-546.

Scott, W. R. (2003). Organizations: rational, natural, and open systems (5th ed.): Englewood Cliffs, N.J.: Prentice Hall.

Senthamil, R., \& Palanichamy, P. (2011). Transformational Leadership Styles and Employee Performance. Journal for Bloomers of Research, 3(2).

Shamir, B., House, R. J., \& Arthur, M. B. (1993). The motivational effects of charismatic leadership: A self-concept based theory. Organization science, 4(4), 577-594.

Tabachnick, B. G., \& Fidell, L. S. (2001). Using Multivariate Statistics (4th ed.). Boston: Allyn and Bacon.

Tan, S. L., \& Lau, C. M. (2012). The Impact of Performance Measures on Employee Fairness Perceptions, Job Satisfaction and Organisational Commitment. Journal of Applied Management Accounting Research, 10(2), 57-72.

Taylor, C. M. (2014). Transformational leadership in a nonprofit organizatin: a case study of a Filipino nonprofit in diverse communities. Temple University.

Teelken, C., Ferlie, E., \& Dent, M. (2012). Leadership in the Public Sector: Promises and Pitfalls: Routledge.

Trottier, T., Van Wart, M., \& Wang, X. (2008). Examining the nature and significance of leadership in government organizations. Public Administration Review, 68(2), 319-333.

Tuuli, M. M., \& Rowlinson, S. (2009). Performance consequences of psychological empowerment. Journal of construction engineering and management.

Van Knippenberg, D., \& Sitkin, S. B. (2013). A critical assessment of charismatic-Transformational leadership research: Back to the drawing board? The Academy of Management Annals, 7(1), 1-60.

Vogel, R., \& Masal, D. (2012). Publicness, Motivation, and Leadership: The Dark Side of Private Management Concepts in the Public Sector. Administratie si Management Public(19), 6-16.

Walumbwa, F. O., Avolio, B. J., \& Zhu, W. (2008). How transformational leadership weaves its influence on individual job performance: The role of identification and efficacy beliefs. Personnel Psychology, 61(4), 793-825.

Walumbwa, F. O., Wang, P., Lawler, J. J., \& Shi, K. (2004). The role of collective efficacy in the relations between transformational leadership and work outcomes. Journal of Occupational and Organizational Psychology, 77(4), 515-530.

Wang, H., Law, K. S., Hackett, R. D., Wang, D., \& Chen, Z. X. (2005). Leader-member exchange as a mediator of the relationship between transformational leadership and followers' performance and organizational citizenship behavior. Academy of management Journal, 48(3), 420-432.

Wang, X.-H. F., \& Howell, J. M. (2012). A multilevel study of transformational leadership, identification, and follower outcomes. The Leadership Quarterly, 23(5), 775-790.

Williams, L. J., \& Anderson, S. E. (1991). Job satisfaction and organizational commitment as predictors of organizational citizenship and in-role behaviors. Journal of management, 17(3), 601-617.

Wright, B. E., Moynihan, D. P., \& Pandey, S. K. (2012). Pulling the levers: Transformational leadership, public 
service motivation, and mission valence. Public Administration Review, 72(2), 206-215.

Yıldız, S., Baştürk, F., \& Boz, İ. T. (2014). The Effect of Leadership and Innovativeness on Business Performance. Procedia-Social and Behavioral Sciences, 150, 785-793.

Yousef, D. A. (2000). Organizational commitment: A mediator of the relationships of leadership behavior with job satisfaction and performance in a non-western country. Journal of Managerial Psychology, 15(1), 6-24.

Yukl, G. A. (1989). Leadership in organizations (2nd ed.): Englewood Cliffs, NJ: Prentice-Hall.

Yukl, G. A. (1998). Leadership in organizations (4th ed.): Englewood Cliffs, NJ: Prentice-Hall.

\section{Copyrights}

Copyright for this article is retained by the author(s), with first publication rights granted to the journal.

This is an open-access article distributed under the terms and conditions of the Creative Commons Attribution license (http://creativecommons.org/licenses/by/4.0/). 